Folia primatol. 1985;45:I-IV

\title{
Contents, Vol. 45, 1985
}

S. Karger $\cdot$ Medical and Scientific Publishers

Basel · München · Paris — London · New York · New Delhi · Singapore · Tokyo · Sydney All rights reserved. (C) Copyright 1985 by

No part of this publication may be translated into other $\quad$ S. Karger AG, P.O. Box, CH-4009

Basel (Switzerland)

languages, reproduced or utilized in any form or by any Printed in Switzerland by Thür AG

Offsetdruck, Pratteln

means, electronic or mechanical, including photocopying, recording, microcopying, or by any information storage and retrieval system, without permission in writing from the publisher or, in the case of photocopying, direct payment of a specified fee to the Copyright Clearance Center (see 'Information for Readers and Subscribers').

Index Vol. 45,1985

No. 1 Differences in Social Behavior between Ethiopian and Arabian Hamadryas Baboons

Kummer, H.; Banaja, A.A.; Abo-Khatwa, A.N.; Ghandour, A.M 1

Adult Male Sociality and Reproductive Tactics among Orangutans at Tanjung Puting

Galdikas, B.M.F $\quad 9$

The Nigerian Guenon, Cercopithecus erythwgaster: Ecological, Behavioral, Systematic and Historical Observations

Oates, J.F 25

Duration of the Third Stage of Labor in a Female Yellow Baboon from Mikumi National Park, Tanzania

Phillips-Conroy, J.E.; Rogers, J.A 44

Morphology and Variation in the Posterior Dentition of Picrodus siiberlingi (Picrodontidae) Williams, J.A 48

Book Review 59

Announcement

No. 2 Structural and Mechanical Indicators of Limb Specialization in Primates

Schaffler, M.B.; Burr, D.B.; Jungers, W.L.; Ruff, C.B 61

Habitat Separation of Semifree-Ranging Lemur catta and Lemur fulvus

Ganzhorn, J.U 76

Revision of Hapalemur (Prohapalemur) gallieni (Standing 1905)

Vuillaume-Randriamanantena, M.; Godfrey, L.R.; Sutherland, M.R 89

Observations on the Interaction between Adult Group Members, Group Members without

Rearing Experience and Infants in the Common Marmoset, Callithrix jacchus

Engel, C $\quad 117$ 


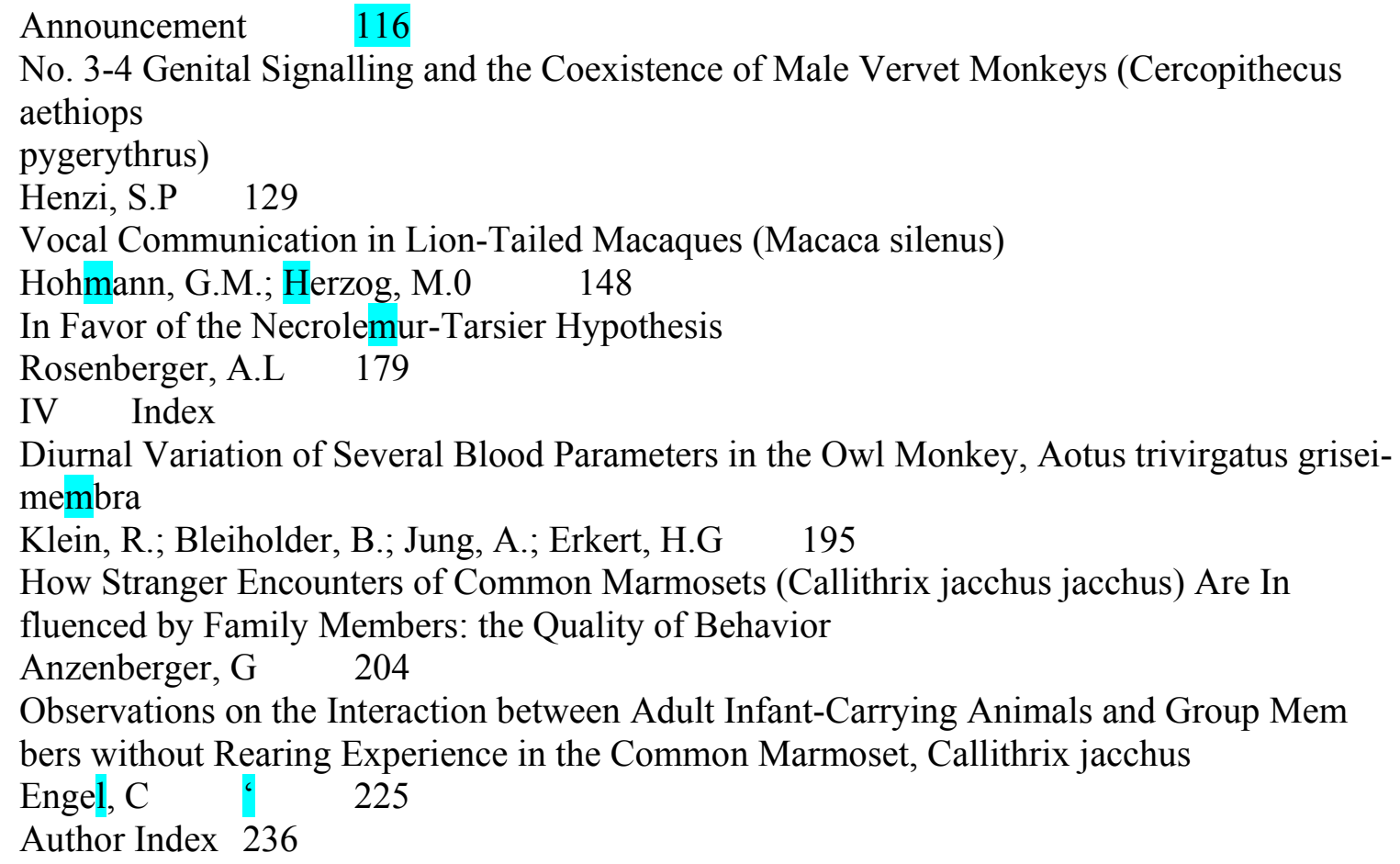

